\title{
Lumen
}

Selected Proceedings from the Canadian Society for Eighteenth-Century Studies

\section{The Argument over Prophecy: An Eighteenth-Century Debate between William Whiston and Anthony Collins}

\section{Stephen Snobelen}

Volume 15, 1996

URI : https://id.erudit.org/iderudit/1012482ar

DOI : https://doi.org/10.7202/1012482ar

Aller au sommaire du numéro

Éditeur(s)

Canadian Society for Eighteenth-Century Studies / Société canadienne d'étude du dix-huitième siècle

ISSN

1209-3696 (imprimé)

1927-8284 (numérique)

Découvrir la revue

Citer cet article

Snobelen, S. (1996). The Argument over Prophecy: An Eighteenth-Century Debate between William Whiston and Anthony Collins. Lumen, 15, 195-213.

https://doi.org/10.7202/1012482ar 


\section{The Argument over Prophecy: An Eighteenth-Century Debate between William Whiston and Anthony Collins}

In this paper I would like to present a defining episode in the intellectual history of the eighteenth century - a period Roy Porter has characterized as a time of secularization among the European intelligentsia. ${ }^{1}$ Clearly, though, there are problems with this sort of sweeping generalization, and even Porter himself attempts to qualify it (72). For one can only argue for a general secularization of the intelligentsia if one ignores the stubborn persistence of the many non-secularized intellectuals who survived the century. This is not to say that Porter's characterization does not hit upon an unmistakable trend in this period. Nevertheless, it was not a universal trend; the dynamics were much more complicated. Secularization has been a rather uneven and erratic phenomenon, progressing quickly in some periods and places and suffering setbacks in others. Moreover, secularization was also occasionally slowed and checked by movements that arose to challenge it: in the British context we need only mention Methodism, along with its nineteenth- and twentieth-century Anglo-American evangelical descendants (Porter 72). Thus, instead of a simple unidirectional view of secularization, in which a religious world view is subsumed by a secular one, I would like to present a model that incorporates secularization as an important element within an overarching intellectual and cultural reconfiguration toward social pluralism. The eighteenth century - particularly in Britain - was a period of growing religious, intellectual and cultural pluralism, within an increasingly tolerant environment. To help illustrate this, I want to look at a public debate that emerged in the early eighteenth century over the literal fulfilment of biblical prophecy. The discussion will focus on the millenarian scientist William Whiston and the freethinker Anthony Collins. While the positions of these two disputants in no way cover the range of religious opinions in this period, the general belief or disbelief in biblical prophecy will here serve as a sort of demarcation point between the religious and the secular. ${ }^{2}$ I will begin by outlining both the 
argument from prophecy and the nature of sceptical attacks against it. Then, I will illustrate how the argument over prophecy constituted an episode in the rise of pluralism and tolerance in the West. In doing this, I also hope this paper will illustrate ways in which the new philosophical and scientific ideas of the period impacted on the culture of prophetic interpretation.

First, we need to define prophecy. In the biblical sense the term 'prophecy' refers to the moral message of the Hebrew and Christian prophets, often accompanied by a predictive element. Under Hellenistic influence during the patristic and medieval periods, Christian scholars began to allegorize and spiritualize biblical prophecy, thus reducing the original temporal and historical force. ${ }^{3}$ In the Reformation, however, the Protestant emphasis on sola scriptura, along with a more literal and historical approach to exegesis, brought about a rehebraicization of prophecy that led to a return to more literal exegetical methodologies. ${ }^{4}$ When one considers that approximately one third of the Protestant Bible contains prophetic writings, it is not surprising that the increased biblical literacy of the Reformation was coupled with a resurgence of interest in things apocalyptic. By the seventeenth century, in fact, prophecy came to occupy roughly the same apologetic place for some Protestants as the continuance of miracles did for many Catholics; fulfilled prophecy became an apologetic tool with which to establish the certainty of the Christian faith. From this emerged a new use of prophecy in the seventeenth century: a sustained polemic against the perceived rise in unbelief. This is the argument from prophecy. Many believing intellectuals saw prophecy as a better argument for Christianity than the design argument, because it specifically supported the Bible, and thus the God of the Bible; design argued for general providence, prophecy for particular providence. Deists believed in the design argument, but this did not direct them to the God of the Bible; prophecy, on the other hand, did this very thing. And so the prophecy argument was believed to offer an infallible testimony to divine revelation and certainty in Christian faith. Advocates of the prophecy argument included Francis Bacon, Henry More, Ralph Cudworth, John Locke, Isaac Newton, and the Newtonians Samuel Clarke and William Whiston. ${ }^{5}$

At the same time, partly because of the new status given to prophecy, freethinkers, deists and infidels were beginning to attack its validity, with much the same intentions as they had been attacking the truthfulness of miracles. To help them do this, critics like Anthony Collins turned back to pagan arguments against Hebrew and Christian prophecy, just as many Enlightenment thinkers reached back to the classical tradition when they began to construct a new world view after they had dismissed the Christian one. Also available to critics was a long tradition of Jewish 
attacks against Christian interpretations of Messianic prophecies. Furthermore, critics and sceptics could turn to the arsenal of recent arguments supplied by the rationalistic and sceptical philosophies and, although they were not that good at it yet, to textual criticism.

Isaac Newton was among those intellectuals who looked to biblical prophecy as a source of certainty and as a polemical tool to combat unbelief. ${ }^{6}$ As William Whiston appears to have fallen partially under the influence of Newton's prophetic views, it will be helpful to provide some examples of Newton's use of prophecy. ${ }^{7}$ Newton fervently believed that the Christian religion was based on the Old Testament prophecies of the Messiah, and among the Old Testament Prophets Newton placed none higher than Daniel, stating that 'to reject his Prophecies, is to reject the Christian religion. For this religion is founded upon his Prophecy concerning the Messiah. ${ }^{8}$ In arguing that prophecy was not given by God to make men prophets themselves, Newton stresses what he feels is a fundamental purpose of prophecy:

He [God] gave this [the Apocalypse] and the Prophecies of the Old testament, not to gratify men's curiosities by enabling them to foreknow things, but that after they were fulfilled they might be interpreted by the event, and his own Providence, not the Interpreters, be then manifested thereby to the world. For the event of things predicted many ages before, will then be a convincing argument that the world is governed by providence (251-52).

This desire for a 'convincing argument' had only recently become a concern for intellectuals like Newton, since the antidote of convincing arguments for Providence is only needed when there is a perceived threat of scepticism and atheism - especially when this involves the denial of biblical revelation and predictive prophecy.

Newton was also intent on developing 'scientific' rules of apocalyptic hermeneutics. ${ }^{9}$ In the introductory comments of a large unpublished treatise on the Apocalypse, Newton outlined several 'Rules for interpreting $\mathrm{y}^{\mathrm{e}}$ words \& language in Scripture' and 'Rules of methodising the Apocalyps.' For example, Newton stressed that only one meaning should be given to a single place in Scripture, ${ }^{10}$ thus reducing to one the possible interpretations of a given passage. Sounding more like a twentieth-century fundamentalist than a father of the Enlightenment, Newton also held it as a principle that one should 'chose those interpretations which are most according to the litterall meaning of the scriptures' (Yahuda MS $1.1 \mathrm{f} .12 \mathrm{r}$ ). He also went on to say that he who

without better grounds then his private opinion or the opinion of any human authority whatsoever shall turn scripture from the plain meaning to an Allegory 
or to any other less naturall sense declares thereby that he reposes more trust in his own imagination or in that human authority then in the Scripture (Yahuda MS $1.1 \mathrm{f} .13 \mathrm{r})$.

Here we see the emphasis on the 'plain,' 'natural' and literal meaning, as well as the distrust of allegory that would come up later in the debate over prophecy. Newton also preferred those interpretations of prophecy ' $w^{\text {ch }}$ without straining do most respect the church \& argue the greatest wisdom \& providence for God for preserving her in the truth'(Yahuda MS 1.1 f.17r). Finally, Newton was emphatic that as good as the argument from prophecy was, prophecy was not intended 'to convert $\mathrm{y}^{\mathrm{e}}$ whole world to $y^{e}$ truth'(Yahuda MS 1.1 f.17r). Here we can detect what is perhaps a slightly different emphasis than that seen in Whiston's agenda. Prophecies, Newton argued, are

so framed by the wisdom of God that $y^{e}$ inconsiderate, $y^{e}$ proud, $y^{e}$ self-conceited, $\mathrm{y}^{\mathrm{e}}$ presumptuous, $\mathrm{y}^{\mathrm{e}}$ sciolist, $\mathrm{y}^{\mathrm{e}}$ sceptic, they whose judgments are ruled by their lusts, their interest, $\mathrm{y}^{\mathrm{e}}$ fashions of $\mathrm{y}^{\mathrm{e}}$ world, their esteem of men, the outward shew of thing or other prejudices, \& all they who, of how pregnant natural parts soever they be, yet cannot discern $y^{e}$ wisdom of God in $y^{e}$ contrivance of $y^{e}$ creation: that these men whose hearts are thus hardned in seeing should see \& not perceive \& in hearing should heare \& not understand. For God has declared his intention in these prophesies to be as well that none of $\mathrm{y}^{\mathrm{e}}$ wicked should understand as $\mathrm{y}^{\mathrm{t}} \mathrm{y}^{\mathrm{e}}$ wise should understand, Dan : 12. (Yahuda MS 1.1 f.18r)

For Newton, prophecy separated the righteous from the wicked.

William Whiston (1667-1752), who was a scientific as well as prophetic disciple of Isaac Newton, took over Newton's position as the Lucasian Chair of Mathematics in Cambridge in 1702 at the latter's desire, only to be drummed out of the University in 1710 for denying the Trinity. ${ }^{11}$ For our purposes Whiston is important as one of the leading advocates of the prophecy argument in the early eighteenth century. In his New Theory of the Earth of 1696 Whiston had stated that 'The Obvious or Literal Sense of Scripture is the True and Real one, where no evident Reason can be given to the contrary. ${ }^{12}$ This principle would guide Whiston throughout his entire life. We see it demonstrated in his Boyle Lectures, which he was called upon to deliver in 1707, and which were published the following year as The Accomplishment of Scripture Prophecies. ${ }^{13}$ The Boyle Lectures, significantly, had been established in the early 1690s with a legacy left by Robert Boyle to set up a series of lectures 'for proveing the Christian religion agt notorious Infidels $\left(v i z^{t}\right)$ Atheists, Theists, Pagans, Jews and Mahometans ..., ${ }^{14}$ 
Whiston opened his first Boyle Lecture by focusing on a text from 2 Peter 1:19, in which the Apostle Peter states: 'We have also a more sure word of prophecy; whereunto ye do well that ye take heed'(Accomplishment 1). Whiston then goes on to contend that the veracity of the prophecy argument is based partly on the fact that the Scriptures themselves presented it (3-4). Early in his first lecture, Whiston also explains that prophecy is 'the most plain and unquestionable evidence that has been produced for the Christian Religion'(2). He then claims that prophecy is so convincing that one has little need of any 'external Illumination or Demonstration to the same purpose'(4).

Whiston's approach in his Boyle Lectures was to outline prophecy after prophecy along with their historical fulfilments. Part of his case rested on the number of fulfilled prophecies that could be amassed as evidence. Thus, Whiston included no less than 300 fulfilments in his Lectures. In outlining these fulfilled prophecies, Whiston hoped to demonstrate the following:

(1) the certainty of the Spirit of Prophecy from the beginning of the World; (2) the Divine Authority of those Sacred Writings, which have all along contain'd the Predictions of future Events, no way within the reach of natural Foresight; (3) the certain truth of the Christian Religion, as it is confirm'd from those ancient Prophecies, fulfilled in our blessed Savior; and (4) the just reasons we have thence to expect the completion of those other Prophecies, which are not a few, whose Periods are not yet come, how little soever we at present are able intirely to comprehend the meaning of them, or to trace the methods and preparations for their Accomplishment (6).

The terms 'certainty' and 'certain truth' stand out in this passage. There is no mistaking the confidence Whiston placed in prophecy.

Now while I certainly do not want to descend too far into the interpretative issues involved in early modern prophetic exegesis, it is essential that we are aware of at least one problem that faced expositors. Christians interpreted many prophecies in the Old Testament as Messianic prophecies fulfilled in Jesus Christ. A classic example is the Immanuel prophecy of Isaiah 7:14: 'A virgin shall conceive, and bear a son.' This passage is identified in Christian tradition, just as in the Gospel of Matthew (1:23), as a prophecy of the virgin birth of Christ. Yet the Prophet Isaiah gave this pronouncement as a sign to Ahaz, king of Judah, over 700 years before Christ's birth. So how could the virgin birth of Christ be a sign to king Ahaz? Christian interpreters dealt with this type of prophecy in different ways. The most common solution was to maintain that the prophecy actually had at least two fulfilments, one in the prophet's own day and one for God's people in the future, with the first 
fulfilment acting as a type of the second, greater fulfilment. Alternatively, the Messianic fulfilment was characterized as the type, and often the term 'typical' was used of the whole methodology. However the terms were employed, typical and allegorical interpretation was standard for most Christians, although the second fulfilment in Christ was always recognized as the greater of the two fulfilments and the most important for theological and apologetic purposes.

Whiston, however, who wanted to set up an exact science of prophetic interpretation, rejected such double fulfilments out of hand. For him, there was only one fulfilment: a literal one uniquely accomplished in the person of Christ. Echoing the Newtonian hermeneutical principle that only a single meaning should be assigned to a single text, Whiston believed that seeking more than one prophetic completion left open the possibility of uncontrollable, multiplying fulfilments. This, he thought, would bring ridicule on Christianity. Whiston argued that

If Prophecies are allow'd to have more than one event in view at the same time, we can never be satisfy'd but they may have as many as any Visionary pleases: and so instead of being capable of a direct and plain Exposition to the satisfaction of the judicious, will be still liable to foolish applications of fanciful and enthusiastick Men (15).

As in his science, Whiston wanted set rules and set parameters. He wanted such controls to reduce the risk that 'fanciful and enthusiastick Men' would be able to discredit the science of prophecy with 'foolish' interpretations. Whiston argued that

A single and determinate sense of every Prophecy, is the only natural and obvious one; and no more can be admitted without putting a force upon plain words, and no more assented to by the Minds of inquisitive Men, without a mighty bypass upon their rational faculties (13-14).

Furthermore, while conceding that the language of prophecy was 'Enigmatical,' Whiston argued that it still possessed 'a sound and rational import, capable of being clearly explain'd to the Reason of Mankind'(9). In all this we see Whiston's desire, perhaps influenced by his background in mathematics and science, to characterize prophecy as a genre that was completely rational in its operation, and distinct and unambiguous in its meaning. In implying that allegory was not scientific, Whiston was perhaps also reflecting the penchant of contemporary natural philosophers for 'plain,' 'unadorned' language.

Additionally, Whiston was already sensitive to the kinds of criticisms sceptics and unbelievers levelled against biblical prophecy: 
If this double intention in Prophecies be allow'd by us Christians, as to those Predictions which were to be fulfilled in our Savior Christ; and if we own that we can no otherwise shew their completion, than by applying them secondarily and typically to our Lord, after they had in their first and primary intention been already plainly fufill'd [sic] in the times of the Old-Testament: We lose all the real advantage of these ancient Prophecies, as to the proof of our common Christianity; and besides expose our selves to the insults of Jews and Infidels in our Discourses with them (16).

In his allusions to the interpretative system of Hugo Grotius, Whiston again reveals his desire to use prophecy for apologetic purposes. Grotius, Whiston claimed, was the first to have reduced the double Sense of Prophecies ... into a regular Scheme. ${ }^{15}$ Yet in his 'Scheme' Grotius argued that only the first fulfilment was literal, while the Messianic completion was only fulfilled in a secondary or typical sense. For Whiston, this was unacceptable; Christianity could not have been founded on anything other than the literal fulfilment of the crucial Messianic prophecies.

While Whiston was not alone in his concern over the lack of precision and potential for abuse with the allegorical method that allowed for multiple interpretations, many of his contemporaries defended it. One writer, William Nichols, recognised that sceptics were fond of attacking allegorical interpretations, and accordingly depicts his deist 'opponent' as saying that 'If we should once allow this typical or allegorical way of explaining Scripture, one might prove the history of Guy of Warwick out of the first chapters of Genesis. ${ }^{16}$ This shows that by the late seventeenth century there was a recognition that allegorical interpretation was a primary target of deist criticism. Yet, while Christian interpreters employed allegory in their interpretation of prophecy, they still contended that both typical and antitypical fulfilments involved particular providence.

The freethinker Anthony Collins (1676-1729), on the other hand, rejected supernatural predictive prophecy outright and presented a third approach. ${ }^{17}$ Like Whiston, Collins was uncomfortable with multiple fulfilments derived from a single text. Collins, too, sought an exact one-to-one correspondence between a single text and a single interpretation. His concerns, stressing 'natural' and 'plain' solutions to interpretative problems, are reminiscent of Whiston's:

Is it not the natural construction of all books, to suppose the person, who is expressly treated of, to be the person really meant, and that another person is not signified thereby, without the plainest evidence from the discourse it self, that the person named is not the person meant? ${ }^{18}$ 
Also like Whiston, Collins thought that the language of the biblical texts should be taken literally, with no recourse to allegory. Unlike Whiston, though, and foreshadowing the views of many modern critical scholars, Collins argued that the only literal fulfilment was the first - the one contemporary with the time of the prophet. All this may seem like a simple debate over what prophetic fulfilment is correct; ultimately, however, it was a debate over the very validity of prophecy itself, and whether it could be used as evidence for Christianity. And Collins' position involved more than an extreme radicalization of Protestant historical and literal hermeneutics. For, while both men shared a belief in single fulfilments, they differed in that Collins implied that no supernatural predictive prophecy had occurred at all, and that the New Testament 'fulfilments' of Old Testament texts and prophecies rested on precarious, strained and unconvincing allegorical interpretations. Simply put, for Whiston biblical prophecy was providential prediction; for Collins it was just contemporary commentary. But it is important to understand that both Whiston and Collins saw the Christian faith (if true) as founded in some way on biblical prophecy. Prophecy was crucial to both of them. ${ }^{19}$

Whiston speaks in his Memoirs of first becoming acquainted with Collins around 1711 at a private salon in the London home of Lady Caverly (1.158). Whiston, who had been introduced to the salon by Samuel Clarke, said that Lady Caverly, 'being a believer, loved to have christians of good reputation come and dine with her, such as she thought Dr. Bradford, Dr. Clarke, and myself,' and that her common-law husband, 'Sir John Hubern, being an unbeliever, loved to have persons like himself; such as Mr. Collins, and Dr. Tyndal, and where accordingly we used to meet, and to have frequent, but friendly debates, about the truth of the bible and christian religion. ${ }^{20}$ Thus early on Whiston and Collins found themselves in a polite and genteel context on opposing sides on issues of belief and Christianity. But the very fact that they were carrying on such a debate in a polite setting is significant. It was not long, however, before the affable exchange that began in private burst onto the public scene.

In 1713 , as part of his agenda to undermine the authority of the Church and increase free debate, Collins anonymously published his manifesto of free thought, A Discourse of Free-Thinking. ${ }^{21}$ Along with an apology for the benefits of free thought, Collins presented in this book anti-clerical rhetoric and material that was intended to undercut the reliability of the Bible. The book, the authorship of which was widely known, was attacked by a wide range of writers: presbyterian biblicists, learned scholars like Richard Bentley, Tories such as Jonathan Swift, and Whigs like Richard Steele, the latter of whom said that its author deserved 'to be 
denied the common benefits of air and water. ${ }^{22}$ This book also brought upon Collins a literary attack from Whiston the same year, Reflexions on an Anonymous Pamphlet. ${ }^{23}$ In his reply, in which Whiston claimed to be in some sense a freethinker himself, he recognized that Collins' book was 'so worded, as to seem rather meant against the Heathen Idolatry, Popish Superstition, real Priestcraft, and Tyranny over Conscience,' but that it was in fact intended to reproach revealed religion and to make the Scriptures appear 'contemptible and uncertain'(3-4).

As we have seen, one aspect of Whiston's prophetic industry involved the production of as many prophetic fulfilments as possible, with the implication that the greater the number of fulfilments, the greater the certainty of the prophecy argument. It was perhaps this quantitative argument that early on led Whiston to attempt to increase the number of divine prophecies by including apocryphal and pseudepigraphal writings - works not found in the Protestant canon. One such work was the Sibylline Oracles, a collection of prophecies generated and elaborated from the mid-second century $\mathrm{BC}$ to the late second century AD first by Jewish and then Christian writers. Thus in 1713 Whiston published a translation of the Oracles, ${ }^{24}$ followed in 1715 by his A Vindication of the Sibylline Oracles. ${ }^{25}$ Whiston, along with others, wanted to argue that these prophecies were authentic. To this end, Whiston sometimes included these prophecies, along with their fulfilments, in his more general works on prophecy. Collins, who likely wanted to move in the opposite direction, would not accept this seemingly gratuitous expansion of the prophetic corpus. Consequently, soon after Whiston published his Vindication, Collins tells us that he was moved to write a manuscript against the work (Scheme 63-64). In his manuscript, Collins argued that the Oracles were 'a forgery made in the times of the primitive Christians, who, for forging them and receiving them, were called Sybilists by the Pagans'(64). This work, however, was never published.

It was not until 1722, though, that Collins and Whiston came into a direct and sustained confrontation with each other. As part of his agenda to illustrate literal fulfilments of prophecy, Whiston wanted to clear up the texts of some Old Testament prophecies that he felt could not be interpreted literally and exactly in their existing form. To do this, Whiston set out on a program of textual criticism to recover the original Hebrew text, which, he argued, the Jewish copyists had corrupted. This work was published in 1722 as the Essay Towards Restoring the True Text of the Old Testament. ${ }^{26}$ It is crucial to understand that Whiston wished to correct the text precisely because he wanted it to support his literal exegetical methodology. As such, Whiston's textual criticism was meant to vindicate the authority of the Scriptures, not weaken it. 
Collins, not adverse to using the textual criticism of the Catholic scholar Richard Simon for the purpose of undermining the Bible, would have none of Whiston using this new science to uphold literal prophecy. Collins, in fact, saw Whiston's attempt to do this as a perfect opportunity to press further his goal of subverting both literal prophecy and the Scriptures themselves. ${ }^{27}$ Thus in 1724 Collins published Discourse on the Grounds and Reasons of the Christian Religion - a work directed primarily (or at least ostensibly) against Whiston. Yet, it is instructive that Collins begins his new book by defending Whiston's right to express his opinion in matters of religion. ${ }^{28}$ In the first part of this work, Collins demonstrates that Christianity was founded on the Old Testament and the fulfilment of Old Testament prophecies in the New Testament. Collins contends that if these 'proofs' can be demonstrated to be valid, then Christianity is true; if not, Christianity is false. Moreover, in his introductory remarks, Collins argues that prophecy, if true, is the best proof of all:

Prophecies fulfill'd, seem the most proper of all arguments, to evince the truth of a revelation, which is design'd to be universally promulgated to men. For a man, for example, who has the Old Testament put into his hands, which contains Prophecies, and the New Testament, which contains their completions, and is once satisfy'd, as he may be with the greatest ease, that the Old Testament existed before the New, may have a compleat, internal, divine demonstration of the truth of Christianity, without long and laborious Inquiries (29-30).

Collins, in framing his argument in very similar terms to Whiston, may or may not be sincere in implying that the argument from prophecy would be a valid one if it could be demonstrated in a conclusive fashion. In any case, Collins goes on to argue that the traditional prophetic proofs are in fact merely typical or allegorical, and lists what he believes to be extreme and unconvincing examples of such proofs from the works of Christian commentaries. Collins also claims that the

Proofs taken out of the Old, and urg'd in the New Testament, being, sometimes, either not to be found in the Old, or not urg'd in the New, according to the literal and obvious sense, which they seem to bear in their suppos'd places in the Old, are therefore not proofs according to Scholastick Rules; almost all Christian Comentators on the Bible, and Advocates for the Christian Religion, both antient and modern, have judg'd them to be apply'd in a secondary, or typical, or mystical, or allegorical, or enigmatical sense, that is, in a sense different from the obvious and literal sense, which they bear in the Old Testament (39-40).

Here Collins' obvious implication is that the foundations of Christianity are, like his cited prophetic examples, extremely weak and tenuous - 
or even non-existent. Instead, Collins argues that 'fulfilments' of the Old Testament prophetic texts read most naturally and literally as fulfilments in the prophets' own times. Again, in taking this position, Collins is implying that biblical prophecy contains no supernatural predictive element at all.

Collins devotes the second part of the work to attacking Whiston's industry of recovering the original, uncorrupted Hebrew text. One of Collins' main contentions here is that the result of Whiston's venture into textual criticism would be subjective, hardly an advance and nothing more than 'a mere WHISTONIAN BIBLE'(225). Collins concludes this part of his book with an extended argument against Whiston's literal scheme, arguing that the proposed prophecies have not been fulfilled literally, while at the same time reinforcing his own interpretative methodology.

Whiston met Collins' Discourse with three separate replies. In his first reply, A List of Suppositions (1724), Whiston answered thirty-three points raised in the Discourse, including Collins' contention that New Testament prophetic fulfilments were not literal and his claim that textual support for the Bible was weak. In his conclusion, Whiston again reveals the markedly Newtonian nature of his prophetic faith. Whiston, himself no stranger to experimental demonstrations, claimed that comparing Collins' cited modern authorities to 'real and original Evidence' was like 'opposing a Cartesian Hypothesis or Romance, to Mr. Boyle's Experiments,' or 'A Metaphysick or Superior Reason of Mr. Leibnitz, against Sir Isaac Newton's Experiments and Demonstrations. ${ }^{29}$ For Whiston, fulfilled prophecy was as empirically certain as a Boylean experiment or a Newtonian demonstration. Finally, after associating his adversary with the two above-named great enemies of Newtonian scientific and philosophic faith, Whiston also includes a personal attack on Collins' morals, accusing the latter of hypocrisy for publicly taking an oath on the Bible, and even receiving communion '[n]otwithstanding his open and profess'd Infidelity'(16). Noting that his opponent spoke of 'the Pious Frauds, and Priestcraft of the Primitive Christians,' Whiston in turn labels Collins' actions as 'gross Immorality, Impious Fraud, and Laycraft'(16).

The text of Whiston's second reply, The Literal Accomplishment of Scripture Prophecies, consists largely of page after page of prophetic predictions listed beside their historical completions or conjectured fulfilments. ${ }^{30}$ Here we see Whiston multiplying examples of fulfilments with only the thinnest of commentary and justification, evidently believing that the predictions and their assigned completions would be testimony enough. Two features of this reply in particular are worthy of comment. First, it is a perfect example of Whiston's belief that the greater the number of prophetic fulfilments one could muster, the stronger the 
case would be for prophecy. Whiston would later boast that his Boyle Lectures contained almost 300 fulfilments, and this book 200 (Supplement 1). However, Whiston may have acted too earnestly by enforcing on himself these quantitative demands, for the simple accumulation of fulfilled prophecies would hardly convince someone like Collins, who had rejected the very premise of supernatural prediction in the first place. Second, James Force is correct when he argues that what Whiston is doing here is closely analogous to Newtonian experimental philosophy (Force 86-87). Whiston produced, in effect, a textbook of replicated prophetic experiments. The reader could read the prediction, and 'test' it against the supplied historical fulfilment, thus 'virtually' participating in a providential event of another time or place. ${ }^{31}$

Finally, Whiston's 1725 publication, A Supplement to the Literal Accomplishment of Scripture Prophecies, although not a direct reply to Collins, still served to expand his industry of literal prophecy by acting as an extension to his Literal Accomplishment. Collins, for his part, saw fit to include this work in his list of the thirty-two replies to his Discourse on the Grounds and Reasons (Scheme xii), and also answered some of the propositions presented in it (Scheme 274,275).

The next publication in the controversy, Collins' Scheme of Literal Prophecy Considered, first published in 1726, was Collins' most sustained and sophisticated attack on prophecy. This book was not written primarily against Whiston, but rather against Edward Chandler, Bishop of Lichfield and Coventry, who had responded in print to Collins' Discourse of $1724 .{ }^{62}$ In this book Collins again attacks the idea of literal predictive prophecy, arguing anew that the New Testament fulfilments are merely and only allegorical. Nor was this new book only an attack on predictive prophecy; by seeking to undermine prophecy, Collins also sought to weaken support for traditional Christian doctrines:

My general observation is, that the new Testament being built on the old, and every where appealing to it, and sending men to search it, and quoting it in order to convince and persuade men of the truth of Christianity and its several doctrines, cannot well be supposed to mean, that men should go thither to search for phrases and similes, but that they should go thither for real instruction in the grounds and reasons of Christianity and its doctrines; which, since they could not have by considering, arguing and reasoning from the literal sense thereof, as is apparent, it remains, that they must go thither to find out the grounds and reasons thereof in the typical, enigmatical, sublime, and secundary sense ...(Scheme 361-62).

Collins here implies that the foundations of Christianity are by no means built on solid proofs, but rather on subjective arguments at the level of allegory. If this is so, Collins argues, the New Testament (with its 
fulfilments of Messianic prophecies) is not founded on the Old, but involves nothing more than 'mere accommodations of phrases' and 'has no more relation to it than the works of Virgil'(Scheme 362). Moreover, Collins pushes his case further by adding the argument that the Old Testament prophets themselves had no intention of presenting the typical meanings that are assigned to their prophecies in the New Testament (377-79). Furthermore, perhaps revealing that he saw the system of Grotius as a stepping stone to his own, Collins devotes an entire chapter in his Scheme to defending the Grotian emphasis on the literalness of first fulfilments (379-402). In his new work, Collins attempts to destroy each of the several proposed literal fulfilments given by Bishop Chandler, including Daniel's famous prophecy of the seventy weeks, which Collins calls the 'sheet Anchor' of Chandler's cause (173). Another of Collins' arguments focuses on the fact that different commentators sometimes contradict each other by offering different fulfilments for the same biblical prophecy (166-68). Collins also acknowledges that were a prophecy proven true, it would in fact be a real miracle (275). Collins just infers that he has not come across any examples that he finds sufficiently convincing.

In addition to the material directed against Chandler, Collins also includes in his Scheme two significant and direct attacks against Whiston. First, Collins includes a response to Whiston's Literal Accomplishment of 1724 (267-80). Collins attacks this work on no less than thirteen points, including the fact that Whiston uses 'unproved, arbitrary and strange rules'(268-71), that Whiston cannot include unfulfilled prophecies as literal accomplishments (271), as well as challenging Whiston to provide a biblical prophecy as clear as Seneca's supposed prediction of the discovery of America and Greenland (275). Collins is also quick to assail Whiston's good judgment, by observing that Whiston had a tendency to accept as genuine prophetic works items such as the Sibylline Oracles and the Apostolic Constitutions that Collins points out were rejected as forgeries by 'learned Men'(278-79). Then, in an appendix, Collins attempts to savage Whiston's sixth century B.C. dating of the book of Daniel. ${ }^{33}$ Following the centuries-old argument of the pagan neo-Platonist Porphyry, Collins claims that the book of Daniel was pseudepigraphal and was actually composed in Maccabean times, thus placing it contemporary with some events Whiston (and others) claimed were actually fulfilments of prophecy. Once again, Collins' contention is that no real or literal prophecy has occurred.

Clearly, Collins' attacks struck a nerve. The large number of replies he received alone demonstrates how important many Protestant writers felt the issue to be. In the end, however, neither Whiston nor Collins convinced the other of his views. Whiston for his part did not feel that 
Collins had answered his convincing prophetic proofs (Memoirs 2:165). As late as 1750 , two years before his death, Whiston was still presenting through public lectures series of prophecies with their historical completions (Memoirs 2: passim). Collins, on the other hand, never came to accept the possibility of predictive prophecy. Nevertheless, there were several areas of agreement. Both Collins and Whiston believed that prophecy was crucial in either establishing or destroying Christianity, and consequently each used prophecy to further their respective agendas. Both Collins and Whiston were locked into the belief that prophecy had to be demonstrated 'rationally' if it was to be proven true. Both men felt the same irritation over double fulfilments, with each arriving at a position that only allowed single interpretations. Both disputants sought support in the new discipline of textual criticism. Both shared a scientific outlook towards prophecy, demanding strict linguistic rules and rejecting typical interpretations. And both were informed by the new scientific age in which they lived. So the respective approaches of the two men were not completely incommensurate; Whiston and Collins could not have been speaking completely different languages, or the debate could not have continued as it did. They both identified the same interpretative problem (multiple prophetic fulfilments), but extricated themselves from the difficulty in quite different ways. Although each departed from the orthodox position that allowed for dual fulfilments, their separate paths reveal their different philosophical predilections. Whiston, the believer, chose to uphold single Messianic fulfilments that explicitly demand supernatural prediction; Collins, by seeking single fulfilments contemporary with the prophets, denied it. In the end - despite the commonalities - each view represented a distinct belief system: one assuming particular providence, the other rejecting it. While a new view emerged, the one did not take over the other. Thomas Kuhn has little to say here; there was no decisive, universal paradigm shift. And any attempt to enforce such a model would be artificial, unsophisticated and myopic, rendering invisible the continued existence of non-secularized intellectuals. Thus, by the latter part of the eighteenth century we see a world in which both the Enlightenment historian Edward Gibbon could refer to expositions of prophecy as 'obscure and unprofitable researches, ${ }^{34}$ and one in which the chemist Joseph Priestly could fervently hold to the prophecy argument as a certain defense of the Christian faith. ${ }^{35}$ A new intellectual world was emerging in which the dominant trend would be plurality. ${ }^{36}$

When I started my research into the vicissitudes of prophecy in the early modern age, I began with the preconception that I would, inter alia, outline the fall of the prophecy argument at the intellectual level in the face of rising secularization. While this characterization certainly con- 
tains some elements of truth, it by no means tells the whole story in all its tangled complexity and manifest incongruities. Surveys of nineteenth-and twentieth-century apocalyptic thought now indicate to me that there are just too many examples of continued intellectual and academic advocacy of prophecy to be ignored. And what is not even true of the intelligentsia, is hardly valid of the other strata of society. The model I am proposing here identifies the emergence of a new rationalist and sceptical world view to compete with the traditional Christian notions of reality (at the same time recognizing that neither of these views are completely homogeneous). But Collins' aim was not simply to engage in a polite debate over the validity of biblical prophecy. He was also determined to undermine the powers of the Church and clergy. In doing this, sceptical thinkers like Collins successfully carved out for themselves a niche in the public forum of ideas, which is exactly what Collins had desired in 1713 when he published his Discourse of FreeThinking. This niche has survived, but so has prophecy and its associated world view - albeit marginalized at the intellectual level and by tacit agreement excluded from the standard intellectual discourse. Still, fundamental changes did occur. For critics of Christianity and prophecy, the expansion of the secular sphere brought with it the construction of an intellectual apparatus with which one could be an informed rejector of prophecy and particular providence. But an irrevocable and enduring legacy of the bifurcation of the Western world view was that Christian advocates of prophecy could no longer be naturally literal in their belief in prophecy and revelation. Instead, after the work of the critics informed biblicists could only be reactively or consciously literal. ${ }^{37}$ That is, these believers are aware of alternative paradigms - perhaps even intimately - but they consciously choose to reject them. And Christian advocates of prophecy, too, developed a confirming intellectual apparatus that could help them retain their beliefs in the new realities of a plural world.

It is also interesting to see the arena of the debate outlined in this paper move from private to public - a movement that perhaps reflects the increasing toleration of the age. Moreover, it is most significant that Whiston, a recognized heretic, and Collins, a known infidel, could then go on to continue their debate in such a public forum as the print media. In their own ways, both men pushed free debate; Collins even recognized Whiston's role in this, for all their philosophical differences. Both men were outside orthodoxy, yet both managed to establish public platforms for their views. It is also worth noting that the two reached an impasse, and neither was compelled (intellectually, socially or legally) to alter his views or recant his positions. The debate, for all its enmity, remained completely literary. This says a lot about what was happening in the 1720s. For in the end Whiston and Collins both walked away all 
the more convinced of their original views - each with a supporting intellectual apparatus. While at one level this is hardly surprising, it must be remembered that it was the increasingly tolerant and plural environment of eighteenth-century Britain that gave them this freedom to choose. For this debate could not have occurred fifty years earlier; certainly not a hundred. And this is exactly the point. ${ }^{38}$

\section{STEPHEN SNOBELEN \\ University of Victoria}

\section{Notes}

1 Roy Porter The Enlightenment (London: Macmillan, 1990) 72.

2 This is not to say that I am proposing that prophecy was the only - or even the main - demarcation point. Furthermore, within early eighteenth-century Anglicanism, prophecy was viewed and used differently by different members of the Church. Often, it was theological radicals who made the most enthusiastic claims for it. Still, even with these qualifications, virtually all believers assented in some way to supernatural predictive prophecy.

3 I am arguing that this shift away from literal apocalyptic eschatology was reinforced by what Reformation scholar George Huntston Williams calls the 'acute Hellenization' of the patristic period; that is, the subordination of the original Hebraic character of the Judeo-Christian scriptural tradition to the forms and abstractions of Greek philosophical thought. We can extend William's observations to the medieval period, noted as it is for its Scholasticism. Part of this process of Hellenization involved a de-emphasis on the literal interpretation of the biblical text. As Williams points out, however, the Reformation was a period of 'acute Hebraicization,' which saw a return to an emphasis on the Hebraic elements of Christianity, especially the scriptural tradition. See Williams, The Radical Reformation, 3rd ed. (Kirksville, Mo.: Sixteenth Century Journal Publishers, 1992) 12.

4 For the development of more literal apocalyptic thought in the sixteenth and seventeenth centuries, see Katherine R. Firth, The Apocalyptic Tradition in Reformation Britain 1530-1645 (Oxford: Oxford University Press, 1979); Paul Christianson, Reformers and Babylon: English Apocalyptic Visions From the Reformation to the Eve of the Civil War (Toronto: University of Toronto Press, 1978); Bryan W. Ball, A Great Expectation: Eschatological Thought in English Protestantism to 1660 (Leiden: E.J. Brill, 1975); Peter Toon, ed. Puritans, the Millennium and the Future of Israel: Puritan Eschatology 1600-1660 (Cambridge \& London: James Clarke, 1970).

5 The importance of biblical prophecy and millenarianism as an intellectual force for such thinkers is demonstrated in Richard H. Popkin, 'The Third Force in Seventeenth-Century Thought: Skepticism, Science and Millenarianism,' in The Prism of Science: The Israel Colloquium, ed Edna Ullmann-Margalit, vol. 2 
(Dordrecht: D. Reidel, 1986) 21-50. See also, Popkin, ed., Millenarianism and Messianism in English Literature and Thought 1650-1800 (Leiden: E.J. Brill, 1988).

6 One of the best treatments of Newton's advocacy of the prophecy argument is James Force's 'Newton's 'Sleeping Argument' and the Newtonian Synthesis of Science and Religion,' in Standing on the Shoulders of Giants: A Longer View of Newton and Halley, ed. Norman J.W. Thrower (Berkeley: University of California Press, 1990) 109-27. See also Force and Richard H. Popkin, Essays on the Context, Nature, and Influence of Isaac Newton's Theology (Dordrecht: Kluwer, 1990).

7 James Force has cogently argued for Whiston's dependence on Newton in his biography William Whiston: Honest Newtonian (Cambridge: Cambridge University Press, 1985). My own reading and comparison of Whiston's prophetic works and Newton's published and unpublished works on prophecy have also revealed distinct similarities, such as a literal approach to interpretation, the belief that prophecy could and should be used against unbelievers, along with a fairly high degree of agreement on the interpretation of the Apocalypse.

8 Newton, Observations upon the Prophecies of Daniel, and the Apocalypse of St. John (London: J. Darby and T. Brown, 1733) 25.

9 I argue that strong analogies can be identified between Newton's scientific method and his principles of prophetic interpretation in my unpublished typescript "A More Sure Word of Prophecy:' Scientific Prophetic Hermeneutics from Napier to Newton.' See also Maurizio Mamiani, 'The Rhetoric of Certainty: Newton's Method in Science and in the Interpretation of the Apocalypse,'in Marcello Pera and William R. Shea, eds., Persuading Science: The Art of Scientific Rhetoric (Canton, Mass.: Science History, 1991) 157-72.

10 Newton, Yahuda MS 1.1, f. 12r. The Yahuda Manuscripts, which include many of Newton's unpublished theological and prophetic manuscripts, are held at the Jewish National and University Library in Jerusalem.

11 The best sources for Whiston's life and works are Force, William Whiston and Maureen Farrell, William Whiston (New York: Arno, 1981). Force's biography contains the best account of Whiston's work on biblical prophecy.

12 Whiston, 'Of the Mosaic Creation,' in A New Theory of the Earth, From Its Original, to the Consummation of all Things. Wherein the Creation of the World in Six Days, the Universal Deluge, and the General Conflagration, as laid down in the Holy Scriptures, Are shewn to be perfectly agreeable to Reason and Philosophy (London: Printed for R. Robert, 1696) 95.

13 Whiston, The Accomplishment of Scripture Prophecies: Being Eight Sermons Preach'd at the Cathedral Church of St. Paul, in the Year MDCCVII (Cambridge: Cambridge University Press/London: For Benj. Tooke, 1708) 1.

14 R.E.W. Maddison, The Life of the Honourable Robert Boyle, F.R.S. (London: Taylor \& Francis, 1969) 274.

15 Whiston, A Supplement to the Literal Accomplishment of Scripture Prophecies (London: Printed for J. Senex, et al, 1725) 3.

16 Nichols, Conference with a Theist (London, 1698), 3: 19. Cited in Force, William Whiston 80.

17 The best account of Collins is found in James O'Higgins, Anthony Collins: The Man and His Works (The Hague: Martinus Nijhoff, 1970). For an older, yet still helpful treatment of Collins' attacks on prophecy, along with the ensuing debate, see 
Leslie Stephen, History of English Thought in the Eighteenth Century, 3rd ed. (New York: G.P. Putnam's Sons, 1902) 201-28.

18 Collins, The Scheme of Literal Prophecy Considered; in a View of the Controversy, Occasioned by a late Book, intitulated, A Discourse of the Grounds and Reasons for the Christian Religion (London, 1727) 282. This is the second edition of this work, the first edition of which appeared in 1726.

19 Whiston may have picked up his affection for prophecy from his contact with Bishop William Lloyd (Whiston, Memoirs of the Life and Writings of Mr. William Whiston, 2nd ed. [London: Printed for J. Whiston and B. White, 1753], 1: 29-31) and Isaac Newton. As for Collins, his awareness of the centrality of prophecy to Christian apologetics may have arisen from his association with John Locke.

20 Whiston, Memoirs, 1: 158. A writer cited in the Biographia Britannica asserts that Whiston met with Collins not more than 'eight or ten times in his life, in a coffee-house or elsewhere, and always in other company' (Biographia Britannica [London: Printed for W. Meadows, et al, 1766], Vol. 6, pt. 2, 1416 n.Q). Over a decade later, Whiston was even to refer to Collins as 'an old Friend.' Whiston, $A$ List of Suppositions or Assertions in the late Discourse of the Grounds and Reasons of the Christian Religion, which are not therein supported by any real or authentick Evidence: For which some such Evidence is expected to be produc'd in Whiston, Proposals for Printing by Subscription; (instead of an Interleav'd Bible, formerly Advertis'd;) Authentick Records concerning the Jewish and Christian Religions: In Three Volumes Octavo; with a large Map, Six Foot Square ([London,] 1724) 16.

21 Collins, A Discourse of Free-Thinking, Occasion'd by the Rise and Growth of a Sect call'd Free-Thinkers (London, 1713).

22 O'Higgins, Anthony Collins 78.

23 Whiston, Reflexions on an Anonymous Pamphlet, Entitulated, a Discourse of Free Thinking (London: Printed for the Author, 1713). Three editions of this work appeared in 1713.

24 Whiston, The Sibylline Oracles, translated from the best Greek copies, and compar'd with the sacred prophecies, especially with Daniel and the Revelations, and with so much history as plainly shews, that many of the Sibyl's predictions are exactly fulfill'd (London, 1713).

25 Whiston, A Vindication of the Sibylline Oracles. To which are added the Genuine Oracles themselves; with the Ancient Citations from them; in their Originals, and in English: And a few brief Notes (London: Printed for the Author, 1715).

26 Whiston, An Essay Towards Restoring the True Text of the Old Testament and for Vindicating the Citations made thence in the New Testament (London, 1722).

27 O'Higgins, Anthony Collins 162.

28 Collins, A Discourse of the Grounds and Reasons of the Christian Religion (London, 1724) iii-lxii.

29 Whiston, A List of Suppositions 16.

30 Whiston, The Literal Accomplishment of Sripture Prophecies. Being a Full Answer to a Late Discourse, Of the Grounds and Reasons of the Christian Religion (London: Printed for J. Senex and W. Taylor, 1724).

31 Steven Shapin and Simon Schaffer have brought to light several aspects of early modern scientific culture, such as the use of 'literary technologies' (printed texts 
and engravings) to allow readers to form a sort of 'virtual' audience by witnessing the experiments through printed media (see Shapin and Schaffer, Leviathan and the Air-Pump: Hobbes, Boyle and the Experimental Life [Princeton: Princeton University Press, 1985]). Whiston, as a public experimental lecturer, made a career out of selling both live and 'virtual' experimental demonstrations. The course book that he produced with his lecturing partner, Francis Hauksbee, Jr., is an example of a literary technology that allowed the reader to witness experiments in a virtual fashion, although remote in time and place from the live demonstrations (see Hauksbee and Whiston, A Course of Mechanical, Optical, Hydrostatical and Pneumatical Experiments [1714]). Whiston's prophetic texts perform a similar function.

32 Chandler, A Defense of Christianity from the Prophecies of the Old Testament, wherein are considered all the objections against this kind of proof, advanced in a late Discourse of the Grounds, Ec. (London, 1725). See Collins, Scheme, ix, 1-2.

33 Collins, Scheme 440-60. Whiston argues for a sixth century dating of Daniel, and thus also for the authority of the book, in Literal Accomplishment 49-53.

34 This is evident in a letter Gibbon wrote to Richard Hurd, then Archdeacon of Gloucester, and later successively Bishop of Lichfield and Worcester: 'Some months ago it was reported, that Dr. Hurd was preparing to expound the Apocalypse, and once more to prove the Pope to be Antichrist. The public were amazed. By the gay and by the busy world, the very attempt was treated as an object of ridicule. Polite scholars lamented, that you should be prevailed on to give up your more solid and liberal studies, for such obscure and unprofitable researches. Your own brethren of the church hinted, that it would be far more prudent to observe a respectful silence with regard to those awful and invidious mysteries' (Gibbon to Hurd, July-August 1772, The Letters of Edward Gibbon, ed. J.E. Norton [New York: The Macmillan Company, 1956], 1: 327). In March 1772 Hurd had published a series of lectures, originally delivered as the Warburtonian Lectures in 1768, under the title An Introduction to the Study of the Prophecies concerning the Christian Church.

35 Priestly, both a millenarian and a scientist, includes a defense of biblical prophecy with an answer to the ancient critics Celsus and Porphyry, in his Letters to a Philosophical Unbeliever, 2nd ed. (Birmingham: Printed by Pearson and Rollason, for J. Johnson, 1787) 191-3.

36 The Enlightenment marks the first time this type of social plurality had existed in the West since the advent of Constantine, prior to which existed another age of multiple word views, complete with intellectual arguments over prophecy.

37 Theologian Paul Tillich introduced these notions of 'natural' and 'reactive' or 'conscious' literalism that I am using to distinguish the pre- and post-Enlightenment experiences of faith. See Tillich, Dynamics of Faith (New York: Harper, 1957) 52-4.

38 I would like to thank James Dybikowski, Michael Hunter, Rob Iliffe and Paul Wood for their helpful comments. 